\title{
An "Alien" or a Stranger Indeed?
}

\author{
Mustafa SWITAT \\ University of Warsaw, Poland \\ m.switat@gmail.com
}

\begin{abstract}
With respect to the current migration crisis in Europe, the term "alien" is generally identified with the Arab or Muslim (for many people: Arab $=$ Muslim) communities. The article contains an analysis of the origins, history, and effects of this phenomenon, illustrated with the example of the Arabs in Poland - a country where both of those communities are small, where there are few immigrants as a rule, and which is not directly impacted by the refugee crisis. In general, there were no negative experiences in Polish-Arabic relations, but-due to the lack of knowledge and personal interactions with members of the Arab (Muslim) diaspora-many Poles perceive them as aliens. Why are they aliens? When did they start being aliens? And if they have always been aliens, then are they aliens indeed?

In the paper, I will present an analysis of the way members of the Arab diaspora are perceived as aliens and their sense of alienness in Poland. The analysis is based on the field study of this community, with emphasis on the differences between the Arab migration to Poland/Eastern European countries and their migration to other European states. Additionally, a new theory of inclusion of an alien will be presented along with proposals concerning how to "tame" an alien for the sake of a common, conflict-free existence-because "alien” often simply means the unknown and/or the unwanted to be known.
\end{abstract}

Keywords: alien, Poland, Europe, the Arab diaspora

\section{Introduction}

In spite of its multicultural past, since War World II, contemporary Poland has been a homogenous state with the absolute domination of a mainstream population, where the level of emigration is higher than immigration. Consequently, the ethnic and religious minorities and a number of immigrants constitute a small percentage of society in Poland. According to the data of The World Factbook (2015), Poland is $134^{\text {th }}$ in the world when it comes to the absolute number of 
immigrants (-0.40 migrants/1,000 population). Poland is also one of the countries of the European Union that has refused to accept refugees (Kacprzak 2016).

Although not affecting Poland directly, the European migrant crisis has deepened the Islamophobic and Anti-Arab atmosphere in Poland, and "an alien" is generally identified with the Arabic or Muslim community. It is so because the uncontrolled wave of immigrants and refugees predominantly comprises inhabitants of Muslim or Arab countries, and negative occurrences related to it are featured in the media. As a result, many myths, exaggerations, and stereotypes of the Arab community, which mostly mirror those foreign experiences where the Arab diaspora is numerous, circulate among the Poles. Due to lack of knowledge and personal interactions with members of the Arab (Muslim) diaspora, many Poles do not perceive them objectively, and Arabs are very often considered aliens.

The aim of this paper is to reflect on the reason why this is happening in Poland:

1) where the Arab diaspora amounts to approximately 10,000-12,000 people (Switat 2015), there is one person of Arab descent per approx. 3,208 inhabitants, and the number of Arabs is much lower compared to the numerosity of the Arab diaspora in Germany, France, or Great Britain (oscillating in hundreds of thousands);

2) while there are generally no negative experiences with this community in Poland (Górak-Sosnowska 2014) as it is in the Western countries (some of the representatives have been residing in Poland for about 40 years) or with the Arab countries. From the beginning of their independence, the Poles helped build the infrastructure and economy in the Arab world (Piotrowski 1989: 5-9). In turn, Arab influences are visible in Polish culture, including science, art, literature, and the Polish language (Skowron-Nalborczyk: 82-83).

Finally, the subject of this paper is: Arabs in Poland-have they been aliens since forever, and are they really aliens?

\section{Researching into the Arab diaspora in Poland}

This article is based on the results obtained during fieldwork conducted from May 2013 to March 2014. A hundred representatives of the Arab community in Poland and (to compare) a hundred Poles were examined using the snowball sampling technique. The research was conducted in twelve Polish cities (where the biggest Polish-Arabic organizations operate), and it is based on a triangulation method (Frankfort-Nachmias and Nachmias 2001: 222-223), meaning the parallel usage of a couple of research techniques (i.e. individual in-depth interviewing, expert interviews, and questionnaires). 
The representatives of the Arab community were recruited according to their date of arrival in Poland. The Arabs who arrived most recently can be considered a "new" diaspora (50 respondents, marked ND in the text), whereas those who came before 1989 (contractual date, which is the symbol of Polish transition and the diametrical change of Arab-Polish relations) and stayed in Poland create an "old" diaspora (50 respondents, marked OD). Three groups surfaced from amongst the Polish respondents: the favorable Poles (FP), the unfavorable Poles (UP), and the undecided Poles (UDP), that is those who replied "hard to say" to the question "Are you favorably disposed to the Arab community in Poland?". Most of the respondents, about two-thirds, declared to be favorably disposed towards the Arabs, while there were a few of those who declared to be unfavorably disposed towards them (Switat 2015). "Undecided" Poles are not against any individuals of Arab descent, but they are against large groups: "Individually—when it comes to each person-yes, as a community I am very afraid of them, and I am afraid of the expansion" (UDP11). This article contains only selected research results (they relate only to the examined representatives of both communities); the complete study over the Arab diaspora in Poland will be soon published.

\section{The Arab/Muslim as alien in Europe-the origin of the concept}

The Poles perceive Arabs as physically and culturally aliens mainly because of their differences in relation to the Polish society. Also, their appearance usually reveals their alien origin (phenotypic difference); so, there are also ethnically visible differences (Modood 2014: 18). Their darker skin exposes them; they are often described as black or dirty. These terms have their origin in the Middle Ages. As for the image of the inhabitants of Arab countries (including Muslims), medieval Christianity, among others, kept on providing examples of stigmatizing attitudes, and the stereotype of a black man as the devil has survived, in a modified form, into the modern times (Sobecki 2013: 66-67).

Many people look at culture mainly through the prism of language, values, and religion, seeing immigrants from outside Europe as definitely different; this predominantly concerns the Muslims. The fear of this religion had existed since the medieval crusades, and in recent years it has been increased by the fear of terrorism despite the fact that only a very small minority of Muslims actually supports radical ideologies. Consequently, the hostility towards Islam and Muslims, called Islamophobia, has lately become quite widespread (Castles and Miller 2011: 322). 
In addition, the contact between Europeans and "primitive" peoples during the first trips overseas resulted in the image of a world with an unmoved order of cultures, where white Europeans occupy the highest place, above the people of Asia and Africa. This belief was propagated by the greatest minds, such as David Hume, Immanuel Kant, Voltaire, or John Locke, and it also served as the basis of Charles Darwin's theory of evolution (Scheffer 2010: 326-333). This opinion indicates ethnocentrism, namely distrust towards people not belonging to a particular culture, combined with a tendency to judge other people's cultures in terms of one's own culture. People from other cultures are regarded as aliens, barbarians, or mentally and morally inferior beings (Giddens 2010: 277). It is worth mentioning that they were assumed as "primitive" people, while according to e.g. Jacek Głuski (1973: 3) European knights, upon arriving in the Arab-Muslim Empire during the Crusades, encountered a high culture and high level of knowledge.

\section{The Arab/Muslim as alien through the history of Arab-Polish relations}

Western Europeans were faster and were the first in the exploration of the Arab world; there were not many expeditions of Polish travelers from the Middle Ages up to the $19^{\text {th }}$ century; they mostly went on pilgrimages, to acquire Arab horses, because of political emigration, or were motivated by romanticism and orientalism (Bystroń 1929, Reychman 1972). Due to the infrequency of direct Polish-Arab contacts, the perception of the residents of Arab countries by the Poles is mainly the result of transferring the Western rhetoric (although Western-Arab contacts have completely different specifics and history, as they are consequences of, e.g. colonization, bringing guest workers/Gastarbeiters, economic migration, or exile; none of these issues concern the Polish-Arab relations).

In Orientalism by Edward W. Said, published in 1970s, the author stated that orientalism is a European ideological creation which imposed stereotypical perceptions of the Orient, especially of Islam, that are still in existence. He drew attention to the fact that the "[t]he Orient was almost a European invention, and had been since antiquity, a place of romance, exotic beings, haunting memories and landscapes, remarkable experiences" (Said 1991: 23). To confirm Said's arguments, there are, for instance, accounts of Polish travelers, including a $19^{\text {th }}$ century Egyptologist, Józef Sękowski, who criticized orientalists for promoting lies about the Arab population, according to which they were wild peoples, while some of the nomadic tribes knew writing, books, literature, and art (Reychman 1972: 128). Almost at the same time, Wacław Rzewuski wrote about 
the naturalness, freedom, and simplicity of the Arab life, one that is full of virtues and spontaneity, arguing that the colorful tales of debauchery in harems are only products of the European imagination (Reychman 1972: 111).

Not counting the individual Arab travelers who arrived to Poland in the Middle Ages, the first numerous group of Arabs in Poland were the Arab students, who started to come to Polish universities in the late 1950s. Poland, like other countries of the Eastern Bloc, responded to the UN call to provide educational assistance to developing countries, the so-called Third World countries, including the Middle East and the North African states, by commencing staff training under the terms of full scholarship granted by the Polish government. More intergovernmental agreements were signed in the following years, resulting in a steady increase in the number of students (Gasztold-Seń 2012: 41, Chilczuk 2001); e.g. an estimated total number of students and $\mathrm{PhD}$ students from the Arab countries in 1987/88 academic year was over 2.5 thousand (Piotrowski 1989: 53-56). Some of these students married Polish women after graduation and remained in the country, creating the "old" Arab diaspora in Poland. They are mainly doctors, engineers, or entrepreneurs, so some kind of an intellectual elite, well-educated and integrated, that knows Polish, works among the native population, and has a higher social status.

Such Polish-Arab marriages are an example of creating double-ethnic families. This is the strongest indicator of overcoming cultural, psychological, and social distance between the members of the host society and immigrants, proving the integration. This type of marriage is considered a connection that exceeds the basic principles-which the group considers to be important for their consistency and, often, even for their existence. Therefore, this is a kind of infraction of the group's boundaries that separate what is one's "own" from what is "alien" (Waldis 2006, Winiarska 2011: 73).

In People's Poland, the perception and treatment of migrants by the Polish society was dichotomous. On the one hand, they were considered bearers of pathological phenomena; the dislike of them and the distrust of the "aliens", an undesirable element in the country, were noticeable. On the other hand, there was an attitude of understanding towards their situation. Polish people saw foreigners as a way of repaying their moral debt to other nations that helped their compatriots abroad (Chodubski 1997: 31-32).

\section{Perceiving Arabs in Polish sociological researches}

The history of creating the image of Arabs in the consciousness of the Poles is very interesting as it is a relatively brief one. The "Arab problem" did not exist and did not arouse the interest of sociologists until the late 1960s. For example, in 1966, Jerzy Szacki studied the attitude of the Poles towards other races and 
nations, but he did not even try to check their attitude towards the Arabs (Szacki 1969). In a 1988 study, an Arab was an "unknown alien" for the majority of the Poles; an "alien" with whom there was very little or no contact and about whom their knowledge was limited (Nowicka 1990: 30). It was known that such a group existed, but it did not function in the consciousness of the Polish society. Jan Nawrocki presumed that the image of Arabs became less amorphous only in the late 1960s, in connection with the events in the Middle East and the accompanying propaganda. The researchers concluded that the respondents felt a deep aversion, and probably fear, towards this group. An Arab was perceived by the Poles as a stranger, angry, and dangerous (Nawrocki 1990: 118-124). Also, different research regarding the Poles' attitude to other nations presents Arabs as the most disliked nation in Poland (Jasińska-Kania 1988, Jasińska-Kania 1992, Public Opinion Research Center 2002-2012). It is worth mentioning that Arabs do not fit the definition of a nation used in the poll, as the name "Arabs" refers to inhabitants of 22 countries.

\section{Presentation of the results of own research of the Arab diaspora in Poland}

However, the majority of Polish respondents have a generalized and universalized image of the Arab diaspora; not much has changed with regard to the perception of Arabs since the research on the distance the Poles have towards different nations, which was conducted in 1988 by the Public Opinion Research Center and published as a book edited by Ewa Nowicka (1990). The Arabs and the Arab culture continue to induce a lot of negative connotations; their perception is largely pejorative and stereotyped, and members of the Arab diaspora talked about a frequent feeling of being treated as second-class (citizens). They are still perceived as strangers, evil, or dangerous, and confused with residents of other countries. Thus, despite the passage of years, the level of knowledge about the Arab diaspora and the distance level towards its members have not changed generally - to paraphrase Znaniecki (1990: 282), strangers remain completely unknown precisely because they are strangers.

Examined Poles towards Arab diaspora (as in any other case) generally exhibit three attitudes: sympathy, antipathy, or impassivity-means from xenophile to xenophobia or other cases of negative social mechanisms related to their perceived "otherness" and "differentness"; besides racism, these are: social distance, prejudice, discrimination, stigmatization, marginalization, exclusion, xenophobia, intolerance, and stereotyping. As a consequence of prejudice, members of the Arab diaspora sometimes become victims of antilocution, that 
is a verbal expression of prejudice, avoidance, discrimination, and physical attacks (Allport 1954: 14-15) and hate speech (mostly Arabs-Muslims, who also experience cases of anti-Islamic racism, Islamophobia). In creating Arabophobia and Islamophobia, myths about Arabs and Islam are extremely harmful, reinforced by media reports on extreme cases on the subject of the functioning of both communities in the Western countries, although Islam in Poland or the Arab diaspora in Poland are not the same as those in the West of which the Poles are afraid of (Switat 2015). In addition, as research shows, the issues of inflow and integration of immigrants have been largely politicized; politicians use the fear of strangers to create a politically resounding problem, which is popular in the media and relatively easy to control and which is why "moral panic" is used to analyze the discourse on immigrants in the Western countries (Garosi 2002). According to Zygmunt Bauman, in this discourse, immigrants are alien, "human leftovers", dehumanized homini sacri-singled out as allegedly guilty of destabilizing the familiar world of host societies (Bauman 2016).

In the case of Polish-Arab relations, there is a cultural contact (mutual perceptions of the two interacting groups) accompanied by adapting difficulties experienced by the host society as well as the immigrants. Alienation is at the core of the mutual attitudes-subjected/subjective (meant as felt towards the other) and reflected/reflective (involves assigning a sense of alienation towards a subject to the other). Furthermore, in the context of the cultural contact, attention should be paid to the category of cognitive readiness as a desire to get to know a foreign culture and having an interest in it, being open to diversity. Lack of cognitive readiness leads to a psychological and social distance. This form of benevolent interest is the bedrock of building an understanding of the alien, excluding —or, at least in a small way, weakening — the sense of alienation and associated negative emotions: revulsion, disgust, fear, or surprise (Nowicka 2011: 11-14). It confirms the opinion of one Arab respondent: "each Pole who does not know Arabs or Arabic countries directly fears hearing the word 'Arab' because they associate Arabs with barbarism, fun and love for women, that is all what they know about Arabs" (ND17).

According to the contact hypothesis by Allport (1954), this contact between the members of two groups could lead to a decrease in the prejudice between them. As Margaret K. (Omar) Nydell (2001: 121) says, "the more frequent and the closer contacts with the Arabs, the sooner a man abandons stereotypes". A similar correlation could be observed when researching the Arab diaspora in Poland: its members usually gain by closer acquaintances-many of the Arab respondents emphasized that although the Poles initially treated them with reserve, they often changed their attitude, to a favorable one, after getting to know them. This can be accompanied by a process that can be called a theory of "including an alien". Each person has a specific set of individuals treated as familiar and a collection 
of individuals treated as strangers; upon meeting an individual from the set of strangers, there is a transference of only that one individual from the stranger set to the familiar set, without changing the attitude toward the entire set of strangers.

In light of this theory, the Poles have imagined a collection of strangers titled "Arabs", which is viewed in a rather negative way, but upon getting to know one of the Arabs personally they change their attitude to a favorable one only towards this single Arab, transferring him/her from the collection of strangers to the familiar set but-characteristically—without simultaneous change in their attitudes or opinions about the general, unspecified set of "Arabs". The following dichotomy is subsequently revealed: "our" Arab friend is good, while the "other" Arabs remain bad. This was seen in the responses given by the Poles and during the selection of the respondents (referred by the members of the diaspora), although they knew particular Arabs and they had good opinions about them. When answering general questions about members of the Arab diaspora, they were negative, especially when discussing the characteristics of this community, mixed marriages, stereotypes, and their authenticity.

Familiarity/strangeness is therefore relative and secondarily dependent on other characteristics, e.g. cultural or ethnic. A stereotype is a subconscious general construct that is not directly affected by the cognition of an individual that belongs to the product of schematic thinking. Considering the fact that familiarity and strangeness are two distinct sets of feeling, an individual from the set of foreign individuals is gradually moving to the "familiar" set having been met personally, but the feelings toward this foreign group to which the individual belongs to generally do not change. This has been observed among the surveyed Poles who have, e.g. Arab friends, colleagues, or family members; they like and respect only this one particular Arab, but they are able to speak badly and stereotypically about other, generalized Arabs, excluding this representative of the Arab diaspora, whom they personally know, from those negative opinions-the distance felt toward him/her disappears. Similarly, Arabs asked questions, such as if Arabs like/are..., often replied with "they", not "we Arabs", highlighting the gap between the rest of the community, treating the Arab diaspora as a foreign collection. Familiarity and strangeness therefore have certain contractual borders. They are subjective and talked about only when some other group is considered familiar. Besides, it is also relative: the same person may be familiar at some point and then foreign at another. Otherness turns into alienness only when there are emotions and attitudes combined with the perceived otherness (Nowicka and Majewska 1993: 20-21).

Znaniecki (1931: 208) claimed that alienation happens only when there are interactions between people (groups) - it is a function of contacts. Different emotional circuits between groups considering themselves as alien may lead to the isolation and avoidance of contacts. It can escalate into aversion to a 
foreign group (fortified antagonism) or symptoms of active aggression (provocative antagonism). Provocative antagonism is visible towards the Arab diaspora in Poland. Despite the diversity of attitudes amongst the Poles in terms of accepting the Arab community in Poland (the favorable, the unfavorable, and the undecided), respondents from all groups noticed a very important problem the members of the Arab diaspora in Poland face, which is the reluctance displayed by the Polish society expressed with an unfriendly treatment and negative attitudes (including direct attacks) in the everyday life. On the other hand, there are social initiatives against the violence towards foreigners, including campaigns promoting the familiarity of "aliens" propagated in the social media, bearing the hashtag \#bija Naszych ["they beat ours"]: our friends, our neighbors, and our common guests (Klimowicz 2016).

Just as members of the Arab diaspora argue that kindness and other positive attitudes of the host society help them to integrate, the Poles, in the context of integration, also expect positive behavior from migrant populations (respect for the Polish law and Polish culture, adapting to social norms and peaceful merging into the society). Therefore, mutual positive interactions and attitudes of both surveyed communities facilitate the process of integration. On the one hand, such positive attitudes enhance the integration of the immigrant population; on the other hand, they facilitate the acceptance of the integrated immigrant population by the host society.

A spiral of antagonism between the host society and the immigrants follows: unfavorable attitude (including discrimination, prejudice) of the host community can indirectly increase the level of frustration among immigrants and, as a result, increase their negative behavior (e.g. an increase in crime). On the other hand, negative behaviors of immigrants cause an increase in unfavorability and other negative attitudes of the local population towards immigrants.

Thus, according to the respondents, the treatment of migrants affects their integration:

An Arab integrates completely when he has a job here and is treated with respect, it's the best way [to integrate-M.S.]; but integration can't be restricted. When there's racism (...), it restricts integration because when a person has a job and everything, then he subconsciously and naturally integrates, which is sometimes restricted when somebody reminds you that you're not a Pole or something racist, which gives one a reason to wonder about integration (OD19).

Such an unconscious focus on someone's origin hinders integration-at least according to Tamotsu Shibutani and Kian M. Kwan (1965), whose approach was based on Herbert Mead's interactionism. These two scholars found that the way a 
person is treated in a given society does not depend on who that person is but on how that person is perceived. Individuals are subject to categorization and have certain traits and behaviors ascribed to them. As a result of this process, a social distance arises, not in the sense of a physical distance between groups but rather as a subjective state of nearness felt by the individuals. According to this concept, reducing the distance leads to structural assimilation.

The aforementioned opinion corresponds with Amin Maalouf's thesis (2002: 51), according to which the more immigrants feel that their original culture's tradition is respected in their new country, the less they feel hated, intimidated, and discriminated against because of their different identity; the more they are open to the new country's cultural opportunities, the less they cling to their separateness. This theory is confirmed by the German Marshall Fund (2009) survey on trends of immigration: $36 \%$ of respondents in six EU countries (especially in Italy and France) believe that discrimination of immigrants is more of an obstacle to their integration than the lack of willingness to integrate on the part of the immigrants themselves.

Favorable relations with immigrants can bring tangible benefits because they motivate integration and prevent immigration pathologies which spoil the image of the entire community. As indicated by the interviewees' statements about a generalized treatment (collective identity), in the case of the Arab diaspora, there is an effect of homogeneity of the foreign group, consisting in the fact that members of the group are seen as similar to one another, and no attention is paid to the internal diversity of this group (Aronson 2001: 138-139), while this group is recognized as homogeneously pejorative. According to Zygmunt Bauman (2000: 126), an "alien" is "devoid of individuality and uniqueness". In effect, collective responsibility is applied to them-the whole community is blamed for the acts of individuals from this community. For this reason, the members of the Arab diaspora call on greater objectivity and not using the collective identity towards them because people are different and, according to Paul Scheffer (2010: 427), people should be judged on their (individual) merits.

As for the identity of the Arab diaspora, Arab respondents conformingly renounce the collective Arab identity for a national identity. Arabs, although homogeneous in the name, are in fact heterogeneous. According to many authors, the idea that all residents of the Middle East are "Arabs" is a hurtful and untrue simplification (Gadowska et al. 2014: 105). After all, every Arab country, despite some common cultural or religious factors, has a different history, different problems, different interests, and a different ethnic composition. Thus, it would be like generalizing all Europeans and not noticing that there is a difference between being German, French, or Polish; similarly, in the Arab world, the situation of Egyptians, Palestinians, or Saudis is incomparable. It confirms Tariqa 
Modood's (2014: 121) theory that an ethnic group (like Arabs) is a social, not natural, being.

On the other hand, some of the surveyed Poles did not generalize the members of the Arab diaspora (as some Arab respondents indicated), therefore assuming that the most appropriate attitude in their everyday life is evaluating a human being according to his/her individual behavior, not on the basis of his/her origin or imposed affiliation.

The Polish respondents mention various sources of information on the Arab community and culture that have influenced their opinions: television, the Internet, newspapers, books, personal contacts, or work. When it comes to the favorably disposed towards the Arab community, personal contacts are at the basis of their opinions, while the Internet is of secondary importance. The opposite is true as far as the unfavorably disposed are concerned, with the Internet being of primary importance. Thus, opinions are formed either on the basis of general information or through the prism of personal experience.

It should be noted that some Polish respondents: have never personally met a person of Arab descent, do not meet them in private, never visited Arab countries, incorrectly define Arab countries (apart from the correct ones, about 30 other countries were mentioned), do not know the Arab culture, meet members of the Arab community in passing (on a street, in a store, in a restaurant, etc.), or do not know any Polish-Arab marriages. Despite all of that, they still speak of this community extensively, which confirms Perry R. Hinton's view (2013) that stereotypes endure because of limited knowledge.

Since most Polish respondents do not know directly the Arab community residing in their country, it can be said that their opinions of the community were formed on the basis of indirect or general information regarding the Arab community. No research has ever been conducted into the Arab diaspora in Poland before; its members are individuals scattered throughout the country. Those who have blended into the Polish community are mostly part of Polish families, workplaces, or businesses.

Many of the Polish respondents incorrectly believe that every Arab is a Muslim and that every Muslim is an Arab. Consequently, an image of an Arab is based on images of many different nationalities. When asked to name Arab countries, Polish respondents-apart from a couple of correct answers-also mention Afghanistan, Turkey, Pakistan, Iran, and Tajikistan, that is Muslim countries, not Arab countries. It is also possible that they think Arabs inhabit the aforementioned countries. For instance, when answering the question "have you ever been to an Arab country?", one person replied "yes, I've been [three times-M.S.] to Turkey" (UP7). In my research, the majority of Arabs were Muslim, but there are also Christians, atheists, or Druzes, and their level of religiousness varies. 
In Poland, Muslims are not only Arabs but also citizens of Asian or European countries as well as Poles (the Tatars and converts). According to different statistics, there are thirty to forty thousand Muslims in Poland, meaning that they constitute about $0.1 \%$ of the Polish population. Thus, Islamophobia (GórakSosnowska 2014) or Arabophobia and a negative attitude towards immigrants can be called "migrational hypochondria" in Poland; an unfounded, exaggerated fear that has no basis in the actual social situation and that probably comes from observing Western countries with a large number of immigrants and Muslims (including the migrant crisis). In Poland, as in other European countries, they are based on perception of imagined, not real Muslim communities. According to the Ipsos MORI study, "Perceptions are not reality: Things the world gets wrong", carried out in 2014 in 14 European countries on a sample of 11,527 people, the perceived proportion of Muslims in Europe is much higher than the actual onesometimes, it is approx. 5 times higher than in reality (Wojtalik 2015).

Although small in number, this phenotypically dissimilar part of Polish population encounters attitudes of extreme animosity or obsessive hostility towards the so-called "others" or "different" (Sobecki 2013: 66). Seeing them as aliens does not end with the acquisition of Polish citizenship: "The Poles still treat me like a stranger" (OD12); "When they ask me about my citizenship at the office and I say that I am Polish, it is strange, they can't wrap their heads around it. It is not only about the Arabs but about other immigrants as well, even the British or the Italians, even though these cultures are similar to the Polish culture" (OD39).

These statements illustrate the theory of Chavez (2008: 68), who, referring to the concept of "imagined communities" by Benedict Anderson (1991), stated that the full integration of immigrants into the host society is not only based on changes concerning the migrants but also on whether the host society is ready to "imagine" migrants of this category (undocumented, in Chavez's case) as members of its own community.

Considering the citizenship issues, one of the surveyed members of the Arab diaspora recommended a way to combat alienation-introducing a law on citizenship instead of the legal division of society into citizens and foreigners.

There is no modern Act on Foreigners and in general there should not be one because if you single out the foreigners you always treat them separately, and the Act on Citizenship regulates issues of citizenship for all-natives and foreigners; it is a citizenship, instead of we are the Poles and we are citizens by the rule and birth, and they are always foreigners or aliens. There was an action a few years ago in Katowice codenamed "alien"; it was to control the foreigners, whether they have legal residence or not, but the name itself was negative, not called, for example, legalization, the law, help, integration, 
not: "alien". There was a film titled "Alien", where the monster from outer space came and ate people, the same here-this stranger, you need to control him, because he is bad, not good; such mentality is alive among the officials and the Polish authorities (OD21).

Strangeness, according to Simmel (1975) is equivalent to a foreign origin; so, it is not an individualizing characteristic but a feature common to all foreigners (potential or real); aliens are therefore not foreign individuals but a certain category of people of a general character. And this respondent noticed that words describing people from outside of Poland in the Polish language have a subconscious and negatively associated content: the word "foreign" suggests a foreign territorial unit, an "alien", which is-according to etymology—related to the birth and the place of permanent residence of an alien land (Nowicka-Rusek 2012: 322).

According to Znaniecki (1931), to talk about the perception of someone as "foreign/strange", there must be a social contact [interaction-M.S.] and a disagreement as to the meaning of the same values. He thought that the human subject is experienced by the human body as a stranger always and only when there is a social contact between them, based on separate systems of values. Members of the Arab diaspora are suspected of such a dissimilarity of values, but it turned out that many of the respondents shared the same civic, ethical, and individual values as the surveyed Poles. In many cases, they also had a similar attitude toward the Polish society, including issues like migration policy, integration, citizenship, and migration. The members of the "old" diaspora, who fully blended with the Polish environment and adapted to the Polish surroundings, especially emphasized this. Because of that, they got to know both communities and found that there was a convergence of opinions between the Arabs and the Poles. There are also common elements in Polish and Arab cultures and similarities between the Polish and Arab society (e.g. hospitality, strong family ties, the love of children, respect for elders, etc.). Thus, it turns out that the "alien" members of the Arab diaspora in Poland are not so "alien" after all.

\section{Conclusions}

In conclusion, an alien is just an unknown-it is enough to meet him/her, and he/she becomes familiar. It is confirmed by Ewa Nowicka's view (2011: 35) that "a stranger is always the one who is accused of otherness or whose otherness is known, while all that is unknown, or not precisely known, is what is alleged to be other". According to Zygmunt Bauman (1995: 81-82), a stranger is this unplanned, unexpected Third, about whom we know little; therefore, according 
to most of the participants, knowledge and education are keys to accepting the "other" and to fighting the mechanisms triggering racist behavior.

As Edyta Pindel $(2014,9)$ claims, "by helping foreigners, we help ourselves to build our daily living environment, of which they are also members. So, if we leave them alone, it is highly probable that once marked as 'foreign', they will remain aliens not only in the interactive but also in the personal sphere; and this will be palpable to us as far as the quality of our daily existence is concerned, which, looking ahead, will be inevitably becoming more and more multicultural. Therefore (...), we have to learn this multicultural society and allow the inclusion of foreigners into the dominant culture, in the role of active subjects".

According to Zygmunt Bauman (2016: 127-128), conversation is the best way to an agreement and, thus, to coexistence that is mutually solidary, peaceful, and beneficial; and there is no viable alternative to this solution. In turn, Amin Maalouf $(2002,2011)$ connects the strangeness to the identity crisis, as a crisis of the modern world, resulting not only from the conflict between the West and the East, where, in his opinion, both sides have erred, but from their almost simultaneously exhausted potential. The crisis of identity is a struggle between tradition and globalization, and the hope for survival, peace, and salvation-he claims-is in a culture whose values will open the door for looking at the other as not only "foreign" but as a "partner" who lives in the same world, next to us. And they will finally open the door for a conversation as equals...

\section{References}

Allport, Gordon W. 1954. The Nature of Prejudice. Cambridge, Massachusetts: Addison-Wesley Publishing Co.

Anderson, Benedict. 1991. Imagined Communities: Reflections on the Origin and Spread of Nationalism. London: Verso.

Aronson, Elliot. 2001. Człowiek - istota społeczna [The Social Animal]. Warsaw: PWN.

Bauman,Zygmunt. 1995. Wieloznaczność nowoczesna, nowoczesność wieloznawcza. [Modernity and Ambivalence]. Warsaw: PWN.

2000. Globalizacja. I co z tego dla ludzi wynika [Globalization. The Human Consequences]. Warsaw: PIW.

2016. Obcy u naszych drzwi [Strangers at Our Door]. Warsaw: PWN.

Bystroń, Jan Stanisław. 1929. Polacy w Ziemi Świętej, Syrji i Egipcie 1147-1914

[Poles in the Holy Land, Syria and Egypt 1147-1914]. Krakow: Ksiegarnia Geograficzna Orbis.

Castles, Stephen, Miller, Mark J. 2001. Migracje we wspótczesnym świecie [The Age of Migration]. Warsaw: PWN. 
Public Opinion Research Center [CBOS]. 2002-2012. Stosunek Polaków do innych narodów. Komunikat z badań [The Attitude of Poles towards Other Nations. Research Report]. CBOS: Warsaw.

Chavez, Leo R. 1991. Outside the Imagined Community: Undocumented Settlers and Experiences of Incorporation. American Ethnologist 18: 257-278.

Chilczuk, Michał. 2001. 50 lat kształcenia studentów zagranicznych w Polsce [50 Years of Education of Foreign Students in Poland]. Kontakt 7(1). (http://www. copernicus.org.pl/kontakt/chilczuk.htm - last visit on: February 8, 2015).

Chodubski, Andrzej. 1997. Imigranci w Polsce [Immigrants in Poland]. Autograf 5: 14-35.

Frankfort-Nachmias, Chava, Nachmias, David. 2001. Metody badawcze w naukach społecznych [Research Methods in the Social Sciences]. Poznań: Wydawnictwo Zysk i S-ka.

Gadowska,Aspazja,Spyra,Adam,Strzelichowski,Szymon,Trzaska,Katarzyna,UrbanToczek, Anna, Witkowski, Tomasz, Ziębacz, Agnieszka. 2014. Charakterystyka społeczności imigranckich z Ukrainy, Armenii, Wietnamu i krajów MENA, zamieszkującaych województwo małopolskie oraz badane społeczności w świetle analizy dokumentów [Characteristics of Immigrant Communities from Ukraine, Armenia, Vietnam and MENA Countries Living in Lesser Poland District and Examined Communities in the Light of the Documents' Analysis]. In: E. Pindel (ed.), Imigranci w Małopolsce. Między integracja, asymilacja, separacja, marginalizacja [Immigrants in Lesser Poland. Between the Integration, Assimilation, Separation, Marginalization]. 49-116. Kraków: Akademia Ignatianum.

Garosi, Eleonora. 2002. Moral Panic and Social Construction of Migrants as a Security Issue in the Context of Risk Societies [paper at the conference: Transnational Mobility and Security: Conceptual Frames, Experiences and New Perspectives for the European Union, Cecina], 12 July.

Gasztold-Seń, Przemysław. 2012. Arabscy studenci w Warszawie po 1956 r. [Arab Students in Warsaw after 1956]. In: P. Pleskot (ed.), Cudzoziemcy w Warszawie 1945-1989: studia i materiały [Foreigners in Warsaw 1945-1989: Research and Materials]. 41-72. Warsaw: IPN.

German Marshall Fund of the United States. 2009. Transatlantic Trends: Immigration, German Marshall Fund of the United States, Brussels: (http:// trends.gmfus.org/files/archived/immigration/doc/TTI_2009_Key.pdf - last visit on August 15, 2015].

Giddens, Anthony. 2010. Socjologia. Warsaw: PWN.

Głuski, Jacek. 1973. Stosunki polsko-arabskie po II wojnie światowej [PolishArab Relations after WW II]. Warsaw: PISM.

Górak-Sosnowska, Katarzyna. 2014. Deconstructing Islamophobia in Poland: Story of an Internet Group. Warsaw: University of Warsaw. 
Hinton, Perry Roy. 2013. Stereotypes, Cognition and Culture. USA, Canada: Psychology Press.

Jasińska-Kania, Aleksandra. 1998. Postawy Polaków wobec różnych narodów: sympatie i niechęci [Polish Attitudes towards Different Peoples: Likes and Dislikes]. Kultura i Społeczeństwo 4: 95-120.

Jasińska-Kania, Aleksandra. 1992. Zmiany postaw Polaków wobec różnych narodów i państw [Changing Attitudes of Poles towards Various Peoples and States]. In: G. Gęsicka (ed.), Bliscy i dalecy [Near and Far]. 220-232. Warsaw: IS UW.

Kacprzak, Izabela. 11.08.2016. Jedenaście krajów europejskich nie przyjęło uchodźców [Eleven European Countries Did Not Accept Refugees]. Rzeczpospolita (http://www.rp.pl/Spoleczenstwo/308119875-Jedenascie-krajow-europejskichnie-przyjelo-uchodzcow.html - last visit on February 24, 2017).

Klimowicz, Joanna. 2016. Bija naszych! Dzień Solidarności z Uchodźcami. Pokażmy, że nie jesteśmy obojętni [They Beat Ours! Day of Solidarity with Refugees. Let Us Show That We Are Not Indifferent]. Gazeta Wyborcza (http://bialystok. wyborcza.pl/bialystok/1,35241,20827057,bija-naszych-dzien-solidarnosci-zuchodzcami-pokazmy-ze-nie.html - last visit on: January 20, 2017.)

Maalouf, Amin. 2002. Zabójcze tożsamości [In the Name of Identity]. Warsaw: PIW. 2011. Rozregulowany świat [Disordered World].Warsaw: Czytelnik.

Modood, Tariq. 2014. Multikulturalizm. Poznań: Wydawnictwo Nauka i Innowacje. Nawrocki, Jan. 1990. Obraz Arabów [The Image of Arabs]. In: E. Nowicka (ed.), Swoi i obcy [Our and Alien]. 118-124. Warsaw: IS UW.

Nowicka, Ewa. 1990. Swojskość i obcość jako kategorie socjologicznej analizy [Familiarity and Strangeness as Categories of Sociological Analysis]. In: E. Nowicka (ed.), Swoi i obcy [Our and Alien]. 5-53. Warsaw: IS UW.

2011. Blaski i cienie imigracji, Problemy cudzoziemców w Polsce [Pros and Cons of Immigration, Problems of Foreigners in Poland]. Warsaw: WUW.

Nowicka, Ewa, Majewska, Małgorzata. 1993. Obcy u siebie. Luteranie w Warszawie [The Stranger at Home. Lutherans in Warsaw]. Warsaw: Oficyna Naukowa.

Nowicka-Rusek, Ewa. 2012. Między wrogościa a akceptacja. Postawy Polaków wobec cudzoziemców u schyłku PRL [Between Hostility and Acceptance. Polish Attitudes towards Foreigners at the End of People's Poland]. In: P. Pleskot (ed.), Cudzoziemcy w Warszawie 1945-1989: studia i materiały [Foreigners in Warsaw 1945-1989: Studies and Materials]. 311-326. Warsaw: IPN.

Nydell, Margaret K. 2001. Zrozumieć Arabów [Understanding Arabs]. Warsaw: EMKA.

Pindel, Edyta. 2014. Wstęp [Introduction]. In: E. Pindel (ed.), Imigranci w Małopolsce. Między integracja , asymilacja , separacja , marginalizacja [Immigrants in Lesser Poland. Between Integration, Assimilation, Separation, Marginalization]. 7-10. Krakow: Akademia Ignatianum. 
Piotrowski, Jerzy. 1989. Stosunki Polski z krajami arabskimi [Poland’s Relations with Arab Countries]. Warsaw: PISM.

Reychman, Jan. 1972. Podróżnicy polscy na Bliskim Wschodzie $w_{X I X}{ }_{w}$ [Polish Travelers in the Middle East in the XIX Century]. Warsaw: Wiedza Powszechna. Said, Edward W. 1991. Orientalism. Warsaw: PIW.

Scheffer, Paul. 2010. Druga ojczyzna. Imigranci w społeczeństwie otwartym [Immigrant Nations]. Wołowiec: Wydawnictwo Czarne.

Shibutani, Tamotsu, Kian, M. Kwan. 1965. Ethnic Stratification. New York: Macmillan.

Simmel, George. 1975. Obcy [Alien]. In: G. Simmel (ed.) Socjologia. 300-305. Warsaw: PWN.

Skowron-Nalborczyk, Agata. 2011. Orient w oczach Sarmatów [Orient in the Eyes of Sarmatians]. Polityka. Pomocnik Historyczny 11: 82-83.

Sobecki, Mirosław. 2013. Rasizm i antysemityzm a tożsamość kulturowa [Racism and Antisemitism vs. Cultural Identity]. In: J. Nikitorowicz (ed.), Patriotyzm i nacjonalizm. Ku jakiej tożsamości kulturowej [Patriotism and Nationalism. Toward Which Cultural Identity?] 65-75. Krakow: Oficyna Wydawnicza „Impuls”.

Switat, Mustafa. 2015. Społeczność arabska w Polsce - fakty i mity. Raport z badań [The Arab Community in Poland-Facts and Myths. Research Report]. Przeglad Orientalistyczny 3-4: 223-233.

Switat, Mustafa. s.a. Społeczność arabska w Polsce. Stara i nowa diaspora [The Arab Community in Poland. The Old and the New Diaspora]. (awaiting publication).

Szacki, Jerzy. 1969. Polacy o sobie i innych narodach [Poles about Themselves and Other Nations]. Warsaw: OBOP iSP.

The World Factbook. 2015. (https://www.cia.gov/library/publications/the-worldfactbook/rankorder/2112rank.html?countryName=France\&countryCode=fr\&r egionCode=eur\&rank=51\#fr - last visit on: January 14, 2016).

Waldis, Barbara. 2006. Introduction: Marriage in an Era of Globalisation. In: B. Waldis, R. Byron (eds.), Migration and Marriage. Heterogamy and Homogamy in a Changing World. Vienna-Berlin: Lit. Verlag.

Winiarska, Aleksandra. 2011. Rodzina wielokulturowa, czyli małżeństwa polskowietnamskie w Polsce [Multicultural Family, Polish-Vietnamese Marriages in Poland]. In: E. Nowicka (ed.), Blaski i cienie imigracji, Problemy cudzoziemców $w$ Polsce [Pros and Cons of Immigration, Problems of Foreigners in Poland]. 73-96. Warsaw: WUW.

Wojtalik, Mateusz. 2015. Muzułmanie w Europie [Muslims in Europe]. Newsweek (http://www.newsweek.pl/swiat/ilu-muzulmanow-mieszka-w-europie-i-wpolsce-mapa,artykuly,354745,1.html\#utm_source=rasp\&utm_medium= click\&utm_campaign=alertSG - last visit on: February 19, 2017). 
Znaniecki, Florian. 1931. Studia nad antagonizmem do obcych [Studies on Antagonism against Strangers]. Przeglad Socjologiczny 2-4: 1-54.

Znaniecki, Florian. 1990. Współczesne narody [Contemporary Nations]. Warsaw: PWN. 